Check for updates

Montreal, Canada

Cite this as: $B M J$ 2021;373:n1536 http://dx.doi.org/10.1136/bmj.n1536 Published: 15 June 2021

\title{
Covid-19: Vaccine doses expire in US as uptake falls by $68 \%$
}

\section{Owen Dyer}

Millions of vaccines are in danger of being thrown out as the US immunisation campaign hits a wall of vaccine refusal. The US led Canada in first dose coverage by $45 \%$ to $35 \%$ at the beginning of May, but since then Canada has added a further $29 \%$, and the US just $7 \%$.

US vaccinations peaked at more than 3.4 million a day in April but fell to under a million a day at the beginning of June, with many sites seeing only a trickle of visitors. Vaccinations have since increased to about 1.1 million a day, as states rolled out incentives including cash giveaways.

But the slight improvement is not enough to put the country back on course for President Biden's target of at least partially vaccinating $70 \%$ of US adults by 4 July. Instead, states are on course to throw out millions of doses that will expire before people can be persuaded to take them.

Oklahoma holds more than 700 ooo doses but is only administering 4500 a day, and has 27 ooo Pfizer and Moderna doses that will expire at the end of June. It is one of several states that have stopped requesting new vaccine.

The US Food and Drug Administration, on 10 June, extended the Johnson and Johnson vaccine's approved shelf life by six weeks, saving millions of doses that were to expire imminently. But the slow uptake of the Johnson and Johnson vaccine, which polling suggests has lower public confidence since a pause was called to investigate clotting incidents, means that millions more doses are likely to expire before takers can be found. Much of the population still to be reached is made up of those who are vaccine hesitant.

Regional disparities are stark, with southern and conservative states having the lowest vaccine uptake, and coastal states the highest. Vermont, Maine, and Massachusetts lead the way in vaccination while Arkansas, Alabama, and Mississippi bring up the rear.

In Mississippi, 34.9\% have received one dose while $28.1 \%$ have received two, compared with $72.2 \%$ and $61.2 \%$ in Vermont. Mississippi last week sent 32400 doses each to Maine and Rhode Island, and sent 800 ooo back to the federal vaccine pool.

“In Mississippi, if people don't understand how important it is to keep alive, we want to protect other Americans," state health officer Thomas Dobbs told the Washington Post. Regional disparities in vaccination rates are beginning to be reflected in case numbers, the newspaper's analysis found. ${ }^{1}$

\section{Incentives}

In North Carolina, \$25 (£17.75; €20.6) cash cards given out with each vaccination led to a brief spike in takers last week, with a quarter saying the giveaway had influenced their decision, but the state still had to send 1.2 million doses back to the federal pool.

Ohio gave away five $\$ 1 \mathrm{~m}$ dollar prizes as well as scholarships, but the scheme produced only a one week bump in uptake. West Virginia, where vaccine scepticism is high, gave away rifles and pickup trucks among other prizes. New Mexico achieved higher uptake with a \$5m first prize. In Washington State, marijuana dispensaries that doubled as vaccination sites gave out free marijuana joints.

Against this background, President Biden's campaign promise to finish vaccinating Americans before helping foreigners has become untenable, and he announced plans at the $\mathrm{G} 7$ to buy 500 million doses of the Pfizer vaccine for lower income countries. The US is also giving away 80 million doses from stocks originally meant to immunise Americans.

Several states will this week send mobile vaccination units into workplaces, hoping to spur uptake. The delta variant is spreading in the US, and now accounts for $6 \%$ of new cases, the president's medical advisor Anthony Fauci said at a briefing. In some western states it has reached $18 \%$. Pointing to the UK, where it now accounts for over $90 \%$ of new infections, Fauci said, "We cannot let that happen." He urged people to book their second shot.

But the kind of misinformation that has left so many Americans sceptical about vaccines was again on display last week, as an Ohio state legislative committee heard evidence from an osteopathic physician who claimed the covid-19 vaccine magnetises people. 'I'm sure you've seen the pictures all over the internet of people who've had these shots, and now they're magnetised," said Sherri Tenpenny, who was invited to testify by Republican lawmakers. "They can put a key on their forehead, it sticks."

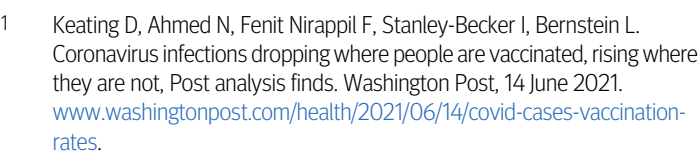

1 Keating D, Ahmed N, Fenit Nirappil F, Stanley-Becker I, Bernstein L. Coronavirus infections dropping where people are vaccinated, rising where they are not, Post analysis finds. Washington Post, 14 June 2021. www.washingtonpost.com/health/2021/06/14/covid-cases-vaccinationrates.

This article is made freely available for use in accordance with BMJ's website terms and conditions for the duration of the covid-19 pandemic or until otherwise determined by BMJ. You may use, download and print the article for any lawful, non-commercial purpose (including text and data mining) provided that all copyright notices and trade marks are retained. 